Patrycjusz Pająk

Data przesłania tekstu do redakcji: 30.12 .2012

p.p.pajak@uw.edu.pl

\title{
Zmierzch bogów w Dubrowniku
}

\begin{abstract}
Pająk Patrycjusz, Zmierzch bogów w Dubrowniku (Twilight of the Gods in Dubrovnik). „Poznańskie Studia Slawistyczne” 5. Poznań 2013. Adam Mickiewicz University Press, pp. 185-201. ISBN 978-83-232-2636-9. ISSN 2084-3011.

The Croatian film Occupation in 26 pictures (1978), directed by Lordan Zafranović is considered as one of the most controversial vision of the Second World War in Yugoslav cinema. The director uses the ornamental style, modeled on Italian cinema, to portray the change of power in Dubrovnik in 1941 - at the beginning of the fascist occupation of the city. He juxtaposes the licentiousness of Italian, German and Croatian fascists and the fall of the Dubrovnik aristocracy and the rebellion of communists. The political changes in the city are presented against the background of its rich cultural tradition. Zafranović highlights the beauty of Dubrovnik's architectural and natural landscape that fascists desecrate. Decadent poetics with its aesthetic excess allows him to refresh and deepen the communist interpretation of the fascist occupation.
\end{abstract}

Keywords: Zafranović; Dubrovnik; Croatian film; Yugoslav film; power; fascism; aristocracy; communism

Dubrownik cieszy się sławą jednego z najstarszych i najważniejszych ośrodków chorwackiego dziedzictwa kulturowego. Od XIII do początku XIX wieku miasto stanowi stolicę niewielkiej republiki i należy do kluczowych portów handlowych w basenie Morza Śródziemnego. Dzięki jego dobrej kondycji ekonomicznej rozwija się w nim, zwłaszcza w czasach renesansu i baroku, kultura elitarna, finansowana i tworzona przez lokalną arystokrację i bogatszych mieszczan pochodzenia plebejskiego. W następstwie wkroczenia wojsk napoleońskich do miasta w 1806 roku Republika Dubrownicka przestaje istnieć, a Dubrownik stopniowo zamienia się w miejscowość prowincjonalną pod względem ekonomicznym i politycznym.

Jakby na przekór tej tendencji w pierwszej połowie XIX wieku renesansowo-barokowa literatura dubrownicka staje się - z uwagi na jej walory 
artystyczne i językowe - jedną z głównych inspiracji dla kultury chorwackiego odrodzenia narodowego. Wspomniane zjawisko nie powstrzymuje jednak obumierania tradycji szlacheckiej w samym mieście. Ten proces w symbolicznym skrócie przedstawia chorwacki dramatopisarz Ivo Vojnović w swoim najsłynniejszym utworze Dubrovačka trilogija (Trylogia dubrownicka, 1902). Opowiada o powolnym upadku społecznym dubrownickiej arystokracji i jej reakcjach na wzrost znaczenia kultury plebejskiej w trzech momentach dziejowych: w chwili zajmowania Dubrownika przez wojska francuskie, w latach trzydziestych XIX wieku i w 1900 roku.

Za swoisty epilog do dzieła Vojnovicia uznać można film Okupacija u 26 slika (Okupacja w 26 obrazach, 1978) Lordana Zafranovicia. Ten pochodzący z Dalmacji reżyser rozpoczyna karierę twórczą w latach sześćdziesiątych w amatorskim klubie filmowym w Splicie, gdzie kręci czternaście filmów krótkometrażowych. Pod koniec dekady wyjeżdża na studia reżyserskie do Pragi. W tym samym czasie, ale także i później, w praskiej szkole filmowej studiuje kilku innych przybyszów z Jugosławii, dlatego ich późniejsze dokonania twórcze określane bywają zbiorczym mianem szkoły praskiej ${ }^{1}$.

W wielu filmach tych reżyserów widać wpływ czeskiego kina nowofalowego lat sześćdziesiątych. W twórczości Zafranovicia więcej jest jednak powinowactw z modernistycznym kinem włoskim w jego ornamentacyjnej odmianie. Mianem ornamentalizmu András Bálint Kovács określa jedną $\mathrm{z}$ głównych tendencji stylistycznych $\mathrm{w}$ europejskim modernizmie filmowym. Wyróżnia ją nasilona ekspozycja folklorystycznego lub mitologicznego kontekstu kulturowego, w którym zanurzony jest świat przedstawiony w filmie. Według Kovácsa wspomnianą tendencję reprezentują między innymi dzieła takich włoskich reżyserów, jak Federico Fellini i Pier Paolo Pasolini. Rafał Syska, który omawia koncepcję węgierskiego filmoznawcy, dodaje nazwiska Luchino Viscontiego i Bernardo Bertolucciego (Kovács 2007: 175-191; Syska 2009: 160-161).

\footnotetext{
${ }^{1}$ Oprócz Zafranovicia szkołę praską reprezentuje inny chorwacki reżyser, Rajko Grlić, a także reżyserzy serbscy: Goran Paskaljević, Goran Marković i Srđan Karanović oraz wówczas bośniacki, a obecnie serbski reżyser Emir Kusturica. Razem z wymienionymi w Pradze studiują też operatorzy filmowi z Chorwacji (Živko Zalar, Dragan Ruljančić, Josip Klarica, Ante Verzotti, Nikša Blajić), Serbii (Predrag Popović, Nevenka Redžić) i Słowenii (Rado Likon, Vilko Filač, Valentin Perko).
} 
Wzorując się na wymienionych twórcach, Zafranović wypracowuje manieryczny i zmysłowy styl, który również można nazwać ornamentacyjnym. Służy on kreowaniu nastroju egzaltacji, będącej w twórczości chorwackiego reżysera kluczem do zrozumienia relacji między rytuałami kulturowymi a pierwotnymi ludzkimi potrzebami i odruchami. Znamiona omawianego stylu nosi już długometrażowy debiut Zafranovicia pt. $\mathrm{Ne}$ delja (Niedziela, 1969) ${ }^{2}$, nakręcony jeszcze podczas studiów w Pradze. Opowiada on o grupie młodych ludzi ze Splitu, którzy pragną zabić niedzielną nudę, próbując różnych rozrywek - od niewinnych do straceńczych.

Okupacja w 26 obrazach to czwarty długometrażowy film Zafranovicia. Reżyser może w nim użyć stylu ornamentacyjnego $\mathrm{z}$ większym rozmachem niż w swoich wcześniejszych, bardziej kameralnych utworach. Film powstaje na kanwie wspomnień dubrowniczanina Mato Jakšicia z 1941 roku, opublikowanych na początku lat sześćdziesiątych ${ }^{3}$. Właśnie w 1941 roku rozgrywa się jego akcja - tuż przed rozpoczęciem okupacji faszystowskiej Dubrownika i w pierwszych miesiącach jej trwania. 10 kwietnia 1941 roku, gdy ustasze ogłaszają powstanie Niezależnego Państwa Chorwackiego, miasto staje się jego częścią. Tydzień później do Dubrownika wkraczają Niemcy. Tego samego dnia w mieście pojawiają się Włosi, którzy przejmują w nim władzę. Lokalni ustasze muszą się im podporządkować ${ }^{4}$.

W okresie włoskiej okupacji Dubrownika trzy zatem środowiska faszystowskie dzielą się najwyższymi wpływami: Włosi (żołnierze oraz funkcjonariusze faszystowskiej milicji - tzw. czarne koszule), oficerowie niemieccy i ustasze. Odrębną grupę uprzywilejowanych obywateli miasta stanowią w filmie Zafranovicia katoliccy duchowni, którzy wspierają okupantów i ustaszy, namaszczając ich panowanie. $\mathrm{Z}$ władzą faszystów pozostają też związani rosyjscy arystokraci (emigranci z czasów rewolucji ro-

\footnotetext{
${ }^{2}$ Film jest rozwinięciem pierwszego, identycznie zatytułowanego, krótkometrażowego filmu amatorskiego Zafranovicia z 1961 roku.

${ }^{3}$ Scenariusz do filmu Zafranović napisał wspólnie z pochodzącym z Czarnogóry, związanym najpierw z Belgradem, a następnie z Chorwacją, pisarzem Mirko Kovačem.

${ }^{4}$ Po kapitulacji Włoch w 1943 roku Dubrownikiem rządzą Niemcy. Okupacja faszystowska miasta (najpierw włoska, potem niemiecka), w której uczestniczą ustasze, kończy się 18 października 1944 roku, gdy zajmują je komunistyczni partyzanci.
} 
syjskiej), a także serwilistyczny burmistrz miasta oraz cyniczny trener szermierki, Hubička (nazwisko wskazuje na czeskie pochodzenie).

W wizji Zafranovicia różnorodny etnicznie i społecznie faszyzm jest estetycznie kolorowy - mieni się barwami i krojami mundurów i garniturów. Przegląd faszystowskiej mody reżyser daje w scenie przyjęcia na cześć okupantów. Zróżnicowanie tego środowiska stanowi w Okupacji w 26 obrazach oznakę totalności jego władzy. W Dubrowniku brakuje przeciwników, którzy mogliby się faszystowskim rządom skutecznie przeciwstawić (to początek okupacji miasta, gdy komuniści dopiero się organizuja). Nadmiar posiadanej władzy faszyści rozładowują, bawiąc się nią, przy czym poszczególne środowiska faszystowskie bawią się władzą inaczej.

W ogólnych zarysach Niemcy, Włosi i ustasze przedstawieni są w Okupacji w 26 obrazach zgodnie ze znanymi stereotypami, przeważającymi w jugosłowiańskich filmach na temat drugiej wojny światowej, które w większości dotyczą komunistycznej partyzantki i - również w większości - utrzymane są aż do rozpadu Jugosławii w poetyce socrealistycznej. Zarazem reżyser wykracza poza te stereotypy, jednak nie przez zaprzeczenie im, ale podkreślenie rzadziej występujących w kinie jugosłowiańskim aspektów lub skrajne nasilenie aspektów już spopularyzowanych.

Na przykład Niemców Zafranović nie kojarzy z wyrachowaną i metodyczną przemocą militarną. W jego utworze nazistów cechuje zmysł estetyczny i wyniosła arogancja typowa dla rasy panów. Gustują oni w elitarnej sztuce i sporcie, lecz przy okazji trywializują te dziedziny. Jeden $\mathrm{z}$ esesmanów robi beznamiętnie zdjęcia turystyczne dubrownickiej starówki, a podczas uroczystego przyjęcia przerywa koncert muzyki klasycznej, aby samemu zaakompaniować na fortepianie do kabaretowej piosenki. Inny funkcjonariusz SS rozkoszuje się pokazem szermierki w zabytkowej sali treningowej. Narusza reguły sportowe dla brutalnego efektu, zmuszając szermierzy, aby obnażyli torsy i walczyli „do pierwszej krwi”.

Również Włochów chorwacki twórca przedstawia z innej strony, niż zazwyczaj czynili to jugosłowiańscy reżyserzy. W ich interpretacji Włosi reprezentują totalitarną przemoc, która nie jest tak zawzięta i niebezpieczna jak przemoc stosowana przez Niemców. Czasem sprawia wrażenie nieporadnej. W niektórych jugosłowiańskich filmach wojennych pojawia się 
ponadto postać Włocha, który sympatyzuje z komunistycznymi partyzantami. Tymczasem w Okupacji w 26 obrazach Włosi to faszyści groteskowi. Pompatyczne wkroczenie oddziałów włoskich do Dubrownika kończy się blamażem (żołnierze podczas defilady ślizgają się na dubrownickim bruku). Groteskowo wyglądają włoscy oficerowie (łysy dowódca, przypominający Mussoliniego, występuje $w$ towarzystwie oficera $\mathrm{z}$ bujną fryzura i kotem). Na ich tle poważniej prezentuje się faszystowski milicjant Toni, którego jednak cechuje pewna delikatność. Włosi w filmie Zafranovicia chcą być nowocześni technicznie i obyczajowo. Defiladę swoich wojsk uwieczniają na filmie, aby później się nim narcystycznie upajać. W jednym z zabytkowych dubrownickich budynków otwierają dom publiczny. Bezczeszczą elitarną kulturę miasta, ale w inny sposób niż Niemcy - żywiołem Włochów jest kiczowate rozpasanie.

Stereotypowy wizerunek ustaszy, ugruntowany w kinie jugosłowiańskim, reżyser przekracza w dwóch wymiarach. Po pierwsze, ich okrucieństwo w Okupacji w 26 obrazach nie ma sobie równego w żadnym jugosłowiańskim filmie o drugiej wojnie światowej. Ustaszom w utworze Zafranovicia sprawia przyjemność prymitywna przemoc. Schwytanych przez siebie wrogów (Żydów, Serbów i nieprawomyślnych Chorwatów) katują na śmierć w autobusie, którym krążą po obrzeżach Dubrownikas. Stosowane przez nich tortury (wbijanie gwoździa w głowę, obcinanie języka, wykłuwanie oczu itp.) przywodzą na myśl krwawe horrory.

Po drugie, reżyser podkreśla, że dubrowniccy ustasze wywodzą się z nizin społecznych, czyli z proletariatu i biedoty miejskiej. Manifestują postawę antyburżuazyjną. Taki wizerunek ustaszy Damir Radić uważa za intrygujący, ponieważ w jugosłowiańskich filmach o drugiej wojnie światowej $\mathrm{w}$ ten sposób charakteryzowano komunistów, podczas gdy ustaszy prezentowano jako popleczników burżuazji (Radić 2000: 67). Zazwyczaj nie poświęcano uwagi ich pochodzeniu społecznemu, uznając, że uosabiają kolaboranckie zło, które nie wymaga dodatkowych wyjaśnień. Pomimo

\footnotetext{
${ }^{5}$ Ów autobus (marki Mercedes-Benz O 3500), znajdujący się w posiadaniu studia Jadran film, ,zagrał” później w jeszcze jednym filmie - w serbskim Ko to tamo peva (Kto tam śpiewa, 1980) Slobodana Šijana. W obydwu filmach przestrzeń autobusu służy przedstawieniu przekroju społeczeństwa (dubrownickiego w Okupacji w 26 obrazach, serbskiego w Kto tam śpiewa) w podobnym momencie historycznym - na początku agresji faszystowskiej na Bałkanach (Okupacja w 26 obrazach) lub w dniu rozpoczęcia tej agresji (Kto tam śpiewa).
} 
skojarzenia ustaszy ze środowiskiem nizin społecznych, reżyser nie dyskredytuje politycznie i moralnie tego środowiska, jako że portretuje również komunistyczny ruch oporu, organizowany przez robotników. Przeciwstawia więc sobie dwa oblicza chorwackiego proletariatu - ustaszowskie i komunistyczne.

Zafranović przedstawia w sumie trzy rodzaje totalitarnej zabawy władzą: quasi-elitarny (Niemcy), plebejski (Włosi) i prymitywny (ustasze). Uzupełnia je trener szermierki Hubička, który znajduje przyjemność w perwersyjnie uprzejmym szantażu, stosowanym wobec osób nieprzychylnych faszystowskiemu reżimowi. Różnice narodowe i społeczne między faszystami nie negują ich ideologicznej wspólnoty, ponieważ sprowadzają się jedynie do sposobów manifestowania władzy. Reżyser pomija kwestię odmienności ideologii nazistowskiej (niemieckiej) od stricte faszystowskiej (włoskiej), jak również kwestię swoistości ustaszyzmu jako syntezy faszyzmu z nazizmem. W filmie, który uwydatnia wulgarność totalitarnego zepsucia, nie ma miejsca na takie ideologiczne subtelności.

Na wizję faszystowskich rządów wpływa w Okupacji w 26 obrazach tło wydarzeń, czyli dubrownicki krajobraz architektoniczno-przyrodniczy, który Zafranović stylizuje na arkadię, nawiązując do mitu Croatia felix, czyli Chorwacji szczęśliwej, składającej się - jak podaje Joanna Rapacka $\mathrm{z}$ wiejskich i miejskich enklaw wolności i harmonii społecznej, rozsianych na obszarze chorwackiego wybrzeża adriatyckiego. Dubrownik uznany zostaje za najważniejszą z tych enklaw ze względu na otaczającą go sławę miasta niezależnego, bogatego i liberalnego (mottem dubrowniczan jest słowo libertas, czyli po łacinie wolność; widnieje ono na jednym z dwóch wariantów flagi dubrownickiej) ${ }^{6}$. Korzenie mitu Croatia felix tkwią w kulturze śródziemnomorskiej i sięgają antyku. Dalmatyńsko-dubrownicka literatura renesansowa i barokowa ugruntowuje wspomniany mit w reakcji

\footnotetext{
${ }^{6}$ Warto w tym kontekście zwrócić uwagę na chorwacko-włoski film Veljko Bulajicia Libertas (Libertas, 2006), nakręcony na motywach biografii najsłynniejszego dubrownickiego pisarza czasów renesansu - Marina Držicia. Bulajić podważa arkadyjski mit dawnego Dubrownika. W przedstawionej przez niego Republice Dubrownickiej panują rządy autorytarne. Cenzura polityczna ogranicza wolność słowa, a niepokorni obywatele muszą emigrować, jeśli nie chcą narażać się na represje, włącznie z wtrąceniem do więzienia. W filmie Bulajicia władze Dubrownika nie cofają się też przed skrytobójczym zabijaniem emigrantów politycznych.
} 
na poczucie zagrożenia ze strony świata zewnętrznego, a literatura chorwackiego odrodzenia narodowego dokonuje jego rewitalizacji, aby podkreślić wielkość dawnej kultury chorwackiej i wyrazić w ten sposób pragnienie jej odbudowy (Rapacka 1984: 10-23; 1997: 106-109).

Zafranović kreuje obraz dubrownickiej arkadii, eksponując walory estetyczne miasta i jego okolic. Miejskie i podmiejskie widoki autor zdjęć do filmu, słoweński operator Karpo Aćimović Godina, utrzymuje w ciepłej i zgaszonej kolorystyce. Nie stroni od kadrów o pocztówkowym czy nawet kiczowatym uroku, jakby wyjętych z albumu reklamującego Dubrownik. Ornamentacyjnej estetyzacji obrazu, która przywodzi na myśl filmy Bernardo Bertolucciego z lat siedemdziesiątych, służy też dynamiczne budowanie ujęć przez płynne łączenie jazd, panoram i transfokacji kamery. Penetruje ona zakamarki przestrzeni i towarzyszy postaciom, przechodząc od jednej do drugiej, w zależności od tego, która $\mathrm{z}$ nich znajduje się w ruchu. Na tej zasadzie reżyser wytwarza wrażenie jednoczesności, żywiołowości i różnorodności przejawów rzeczywistości. Wrażenie to zostaje w filmie poparte wielością powiązanych ze sobą wątków. Poszczególne sceny w Okupacji w 26 obrazach mienią się w konsekwencji zmysłowym bogactwem, dlatego wizja Dubrownika tamtych czasów wydaje się całościowa i nabiera epickiego wymiaru.

Pierwszoplanową rolę w filmie Zafranovicia odgrywa dubrownicka arystokracja. Reżyser kreśli jej profil kulturowy na przykładzie kapitana żeglugi handlowej o imieniu Baldo oraz jego najbliższej rodziny. Korzenie tego środowiska sięgają czasów Republiki Dubrownickiej (na ścianach domu kapitana wiszą obrazy jego przodków, którzy uczestniczyli w życiu publicznym Republiki). Rodzina kapitana podtrzymuje dubrownicką tradycję ekonomiczną (kapitan dowodzi statkiem handlowym) i artystyczną (syn i córka dają rodzinne koncerty na fortepian i skrzypce). Szermierka, którą uprawia jego syn, Niko (ale i inni bogatsi mieszczanie, niekoniecznie pochodzenia arystokratycznego), także przywodzi na myśl szlachecką tradycję Dubrownika, ponieważ stanowi symboliczne przedłużenie dawnych obyczajów rycerskich. Rodzina kultywuje ponadto tradycyjny patriarchalizm. Przewodzą jej mężczyźni (dziadek, ojciec, syn). Kobiety (matka, córka) przyjmują postawę bierną, reaktywną, uczuciową.

Dom kapitana to ośrodek życia towarzyskiego. Spotykają się w nim przedstawiciele różnych środowisk etnicznych i społecznych, co Zafra- 
nović uwydatnia w scenie przyjęcia zaręczynowego córki kapitana o imieniu Ana. Rodzina utrzymuje też przyjazne stosunki z pracującymi dla niej robotnikami. Najbardziej wyeksponowanym w filmie przejawem kulturowego otwarcia dubrownickiej arystokracji jest przyjaźń syna i córki kapitana Baldo z dwoma ich pokoleniowymi rówieśnikami - Włochem i Żydem.

Przyjaźń ta stanowi szkielet fabularny filmu. W pierwszej scenie czwórka przyjaciół bawi się przed domem kapitana w karnawałowych przebraniach. Wraz z rozwojem wydarzeń drogi przyjaciół rozchodzą się z powodu odmiennych poglądów politycznych, a ich losy zostają podporządkowane prezentacji szerszej panoramy społeczno-politycznej. W zakończeniu Zafranović powraca do wątku przyjaźni, kreśląc jej ostateczny krach. Upadek przyjaźni ponad etnicznymi podziałami oznacza w Okupacji w 26 obrazach upadek modelu kultury krzewionego przez dubrownicką arystokrację. Dochodzi do tego w tym samym miejscu, w którym film się rozpoczynał - w domu kapitana Baldo. W zakończeniu przestrzeń ta ma już inny status - nie kipi życiem, związanym z kulturową otwartością środowiska arystokratycznego, ale staje się jego symbolicznym grobem. Dlatego można powiedzieć, że film Zafranovicia stanowi swoisty epilog przywołanego wcześniej dramatu Vojnovicia.

Od tej strony interpretowana Okupacja w 26 obrazach przywodzi na myśl film La caduta degli dei (Zmierzch bogów, 1969) Luchino Viscontiego. W filmie tym do rozpadu szlacheckiej rodziny przemysłowych potentatów, Essenbecków, dochodzi w następstwie przejęcia władzy w Niemczech przez nazistów i nasilonych przez to wydarzenie podziałów wewnątrz rodziny. W podobny sposób rozpada się rodzina kapitana Baldo (kapitan pozostaje wierny konserwatywnym przekonaniom, córka wychodzi za włoskiego faszystę, a syn przystaje do komunistów), lecz proces ten nie zostaje przez chorwackiego reżysera tak pogłębiony psychologicznie, społecznie i politycznie jak w Zmierzchu bogów. Visconti przyjmuje bowiem inną perspektywę jego opisu. Skupia się wyłącznie na grupie arystokratów, dając jej spójny i całościowy obraz w chwili politycznego przełomu, podczas gdy Zafranović, owszem, czyni z arystokratów główny przedmiot zainteresowania, lecz się do niego nie ogranicza, prezentując jak już nadmieniono - szerszą panoramę społeczno-polityczną Dubrowni- 
ka. Nikica Gilić zwraca uwage, że ten zamiar reżysera zapowiada już tytuł filmu. Zgodnie z nim poszczególne sekwencje w Okupacji w 26 obrazach są względem siebie w pewnym stopniu autonomiczne i układają się raczej w mozaikę niż w ściśle kauzalny łańcuch (Gilić 2011: 108).

Inaczej też niż Visconti uzasadnia Zafranović upadek arystokratycznej rodziny. W dziele Włocha krach Essenbecków jest spowodowany przede wszystkim przez czynnik wewnętrzny, czyli przez słabość psychiczną lub moralną członków tej rodziny i wynikającą stąd ich podatność na nazistowską manipulację. Pierwszoplanowymi bohaterami Zmierzchu bogów kieruje żądza władzy, a niektórzy z nich ulegają ponadto seksualnej dewiacji. Essenbeckowie są więc, jak trafnie zauważa Alicja Helman, „bogami” skarlałymi i spotwornianymi (Helman 2001: 242). Taki też charakter ma ich upadek i jest on doszczętny - oznacza śmierć lub degenerację moralną wszystkich członków rodziny.

Zafranović odwrotnie - afirmuje portretowaną przez siebie rodzinę szlachecką, której rozpad w większym stopniu wypływa z czynnika zewnętrznego, czyli niszczycielskiego oddziaływania okoliczności politycznych. Rolę czarnej owcy spełnia w tej rodzinie tylko Toni, który zresztą należy do niej pośrednio - przez ślub z córką kapitana Baldo. Poza tym pochodzi z innego środowiska etniczno-społecznego - z włoskiego mieszczaństwa osiadłego w Dubrowniku. Wierność, jaką Ana okazuje Toniemu pomimo jego faszystowskich poglądów, tłumaczy miłosne zaślepienie, które nie należy do najcięższych grzechów. Pozostali członkowie rodziny wykazują się hartem i niezależnością ducha. Niko, co prawda, ulega politycznej pokusie, ponieważ sympatyzuje z komunistami, lecz ta postawa zostaje przez reżysera moralnie i ideowo usprawiedliwiona.

W przeciwieństwie do Essenbecków rodziny kapitana Baldo nie kazi żądza władzy i seksualna dewiacja. Jedna tylko scena, na co zwraca uwagę Radić, aluzyjnie sugeruje kazirodczą skłonność. Mianowicie, gdy Niko pociesza płaczącą siostrę, zdejmuje z niej sukienkę, obnażając piersi, aby dziewczyna się w ten sposób rozluźniła. To jednak aluzja nieśmiała i nie znajduje potwierdzenia w późniejszych wydarzeniach (Radić 2000: 66).

Upadek arystokratycznej rodziny w Okupacji w 26 obrazach nie jest jak w Zmierzchu bogów - całkowity, choć dwóch jej członków (Baldo i Toni) umiera, a jeden z nich (Toni) wcześniej kompromituje się moralnie. 
Następuje też zerwanie więzi między rodzeństwem (Nico i Ana) oraz utrata pozycji społecznej i majątku przez rodzinę. Nie popada ona jednak w dekadenckie zepsucie jak Essenbeckowie.

Prócz tematu postawy arystokracji w czasach brunatnego totalitaryzmu Okupacje w 26 obrazach zbliża do Zmierzchu bogów obecność intertekstualnych odniesień estetycznych. Visconti nawiązuje do utworów Williama Szekspira i Fiodora Dostojewskiego oraz do opery Richarda Wagnera, ale filmowi patronuje też duch prozy Thomasa Manna. Odwołania do znanych dzieł artystycznych cechują też kilka innych filmów włoskiego reżysera. $\mathrm{Z}$ uwagi na bogactwo wspomnianych odwołań i ich artystyczną syntezę Alicja Helman nazywa te utwory „operami” (Helman 1996: 218-219; 2001: 227-231).

Głównym estetycznym punktem odniesienia w Okupacji w 26 obrazach jest natomiast karnawał, który - podobnie jak opera - stanowi fenomen kulturowy łączący różne dziedziny sztuki, tyle że plebejskiej, a nie elitarnej. Film otwiera sekwencja karnawału ulicznego, podczas którego dubrowniczanie bawią się przebrani w renesansowe stroje. W ten sposób reżyser nawiązuje do tradycji kulturowej Dubrownika czasów renesansu, gdy miasto osiaga szczytowy punkt rozwoju. Karnawałowy wstęp kojarzy film Zafranovicia z twórczością Federico Felliniego, który nobilituje różne formy sztuki plebejskiej, poddając je barokowej stylizacji.

Nastrój idylliczny w sekwencji karnawałowej wzmacnia popularna dalmatyńska serenada elegijna Zvizde mi kažu (Gwiazdy mi mówia), śpiewana przez młodych bohaterów w jej dubrownickim (sztokawskim) wariancie językowym. Opowiada ona o miłości, która trwa po śmierci ukochanego. Ale już po chwili słodka tęsknota ustępuje w omawianej sekwencji frywolnym igraszkom z dubrownicką prostytutką. Nikt jednak naprawdę nie cierpi miłosnych katuszy ani nie ulega seksualnej namiętności, ponieważ w karnawale autentyczna jest tylko radość z zabawy, w której wszystko dzieje się na niby.

Przywołując tradycję renesansowego karnawału, reżyser wskrzesza arkadyjski mit Dubrownika jako miejsca, w którym - jak już wspomniano - panuje wolność i harmonia społeczna. Dzięki przebraniom i maskom, wspólnym śpiewom i tańcom karnawałowa zabawa łagodzi różnice i napięcia między mieszkańcami miasta, ponieważ uwalnia ich na chwilę od 
przypisanej im społecznej tożsamości, co pozwala na jej odnowienie, a tym samym odnowienie relacji z innymi.

Do tradycji dubrownickiej i mitu arkadyjskiego nawiązuje nie tylko sekwencja początkowa, ale też kilka następnych, które obrazują życie w mieście przed okupacją faszystowską na przykładzie takich rytuałów, jak wyprawa członków klubu szermierczego na wyspe, koncert rodzinny po powrocie kapitana Baldo z rejsu czy przyjęcie zaręczynowe Any i Toniego. Również w nich dominuje idylla przezwyciężająca różne podziały. W kontraście do tych sekwencji pokazuje Zafranović sytuację dubrownickich robotników, którzy organizują komunistyczny wiec i zostają pobici przez policję. Wspomniany kontrast zostaje złagodzony przez podskórne podobieństwo atmosfery robotniczego wiecowania $\mathrm{z}$ atmosferą burżuazyjnej zabawy. I w jednym, i w drugim przypadku dochodzi do erupcji kolektywnego witalizmu.

W interpretacji Zafranovicia przedwojenny kapitalizm jugosłowiański, choć nie jest ustrojem idealnym, ponieważ represjonuje niepokornych robotników, to jednak zachowuje w Dubrowniku ducha arkadyjskiego, jako że zasadniczo nie wyklucza porozumienia między odmiennymi środowiskami społecznymi, etnicznymi i politycznymi. Różnice między nimi nie odgrywają większej roli, o ile nie szkodzą porządkowi ekonomicznemu. Dlatego Żyd Miho może razem z Chorwatem Niko i Włochem Tonim trenować w elitarnym klubie szermierczym pod okiem faszyzującego Hubički. Na tej zasadzie kapitanowi Baldo nie przeszkadzają komunistyczne poglądy robotników, o ile wykonują oni solidnie zleconą przez niego pracę.

Dubrownicką idyllę, opartą na społecznej tolerancji, zatruwają faszyści. Nadmiar władzy, jaką dysponują, skutkuje zepsuciem obyczajów. Faszystowskie - stanowią zdegenerowaną wersję obyczajów kultywowanych przez dubrowniczan w okresie przedokupacyjnym. Na przykład idyllicznemu treningowi szermierczemu na wyspie reżyser przeciwstawia pojedynek między szermierzami, do którego dochodzi na życzenie oficera SS. Opozycję wobec przyjęcia zaręczynowego Any i Toniego, odbywającego się przy muzyce $\mathrm{z}$ gramofonu i $\mathrm{w}$ atmosferze przyjaźni, tworzy ślub tej pary, któremu towarzyszy faszystowska propaganda płynąca $\mathrm{z}$ megafonu na głównym placu miasta oraz nagonka na zbuntowanego komunistę. Wiec 
robotników, którzy protestują przeciw burżuazyjnej niesprawiedliwości, ma z kolei odpowiednik w ustaszowskiej masakrze wrogów politycznych.

Faszyści w Okupacji w 26 obrazach używają władzy tak, aby uwydatnić różnice etniczne i polityczne, które są - wedle ich doktryny ideologicznej - nieprzekraczalne i wykluczają porozumienie. Mundury faszystowskie nie służą igraniu $\mathrm{z}$ tożsamością jak przebrania w karnawale mieszczańskim, lecz przeciwnie - jednoznacznie ją określają. Zabawa faszystowska różni się od zabawy karnawałowej, ponieważ nie ma charakteru witalistycznego, ale tanatyczny. Nie odnawia tradycyjnych relacji społecznych przez ich ludyczne zakwestionowanie, lecz je niszczy w wyniku nadmiernego nasilenia władzy.

Daniel J. Goulding trafnie zauważa, że film Zafranovicia opowiada o bezczeszczeniu tradycyjnej kultury dubrownickiej przez barbarzyńskie zło. Pod tym względem Okupacja w 26 obrazach przypomina film Kaja, ubit ću te! (Kaja, zabije cię!, 1969) innego chorwackiego reżysera, Vatroslava Mimicy, który podobną sytuację przedstawia na przykładzie dalmatyńskiego miasta Trogir (Goulding 2004: 160). Faszyści w filmie Zafranovicia reprezentują zło narcystyczne, które chce być piękne w swojej wszechmocy i w tym celu pasożytniczo przyswaja piękno dubrownickiej kultury. Najbardziej dobitnym przejawem wzmiankowanego zjawiska jest przywołana już wcześniej sekwencja ustaszowskiej rzezi w autobusie. Mordowaniu więźniów towarzyszy malowniczy obraz dubrownickich okolic z galopującym białym koniem, który wprowadza do omawianego obrazu pierwiastek kiczu. Za pomocą tej sceny i scen pokrewnych jej ideowo oraz estetycznie, choć pozbawionych drastyczności, Zafranović kreuje w Okupacji w 26 obrazach nastrój piękna przesiąkniętego złem.

Wielokulturowość Dubrownika, podtrzymywana przez środowisko arystokratyczne i polegająca na nieograniczonym etnicznie, społecznie i politycznie otwarciu miasta, zostaje w okresie drugiej wojny światowej zastapiona wielokulturowością faszystowska, która - pomimo swojego etnicznego i społecznego zróżnicowania - jest powierzchowna i zwodnicza, ponieważ skrywa dążenie do totalitarnego ujednolicenia kultury. Wstępem do realizacji tego dążenia jest ujarzmienie, degradacja lub unicestwienie przedstawicieli najważniejszej kulturotwórczej warstwy społecznej w postaci dubrownickiej arystokracji, która władzę polityczną i spo- 
łeczną straciła już dawno w następstwie napoleoniady, lecz - jak dowodzi chorwacki reżyser - ostateczny upadek tego środowiska przynosi dopiero druga wojna światowa. Do tego czasu arystokraci zachowują w Dubrowniku autorytet społeczny oparty na ciagle pokaźnym kapitale ekonomicznym.

W okresie faszystowskiej okupacji tak uzasadniony autorytet okazuje się niewystarczający. W filmie Zafranovicia słabość polityczna arystokracji powoduje, że nie jest ona zdolna do przeciwstawienia się totalitarnej przemocy, która skazuje ją na wyginięcie. Oprócz Żydów, Serbów i komunistów to właśnie chorwaccy arystokraci mają w Okupacji w 26 obrazach status ofiar faszystowskiego terroru. Reżyser podkreśla antyfaszystowską postawę kapitana oraz jego syna, Niko. Wynika ona po części z konserwatyzmu (w przypadku ojca), po części z fascynacji komunizmem (w przypadku syna, choć i ojciec jest komunistom przychylny). We wcześniejszych jugosłowiańskich filmach na temat drugiej wojny światowej przedstawicieli szeroko rozumianej burżuazji przedstawiano zazwyczaj jako sympatyków rodzimego lub okupacyjnego reżimu. Przeprowadzoną przez Zafranovicia rehabilitację moralno-polityczną chorwackiej szlachty Damir Radić uważa za jeszcze jedną - obok porzucenia dogmatu o ideologicznej jedności proletariatu - nietypową z punktu widzenia ideologii komunistycznej i dlatego oryginalną cechę świata wykreowanego w Okupacji w 26 obrazach (Radić 2000: 65).

Jeśli przyjąć, że reżyser przedstawia przypadek rodziny kapitana Baldo nie jako wyjątkowy, lecz reprezentatywny dla poważanej cześci dubrowniczan pochodzenia szlacheckiego, to z punktu widzenia realiów historycznych dokonuje on manipulacji. Podkreśla bowiem jedynie destrukcyjny wpływ totalitaryzmu faszystowskiego na dubrownicką arystokrację, przemilczając niebezpieczeństwo grożące jej ze strony totalitaryzmu komunistycznego.

Komuniści są w Okupacji w 26 obrazach idealizowani zarówno jako przeciwnicy brunatnej przemocy, jak i rzecznicy sprawiedliwości społecznej, choć - w przeciwieństwie do ustaszy - nie manifestują nienawiści do dubrownickich arystokratów, lecz prowadzą z nimi uprzejmy dialog polityczny, uświadamiając ich ideologicznie. Co więcej, sami przejawiają cechy arystokratyczne, które nie wynikają z wielowiekowej tradycji ani z posiadanego majątku, lecz ze szlachetności ducha. Zafranović przypisuje im uczuciową subtelność i zdolność do romantycznych gestów sprzeciwu 
(jeden z komunistycznych działaczy wykrzykuje do tłumu faszystów polityczne hasła, narażając się na lincz). To uszlachetnienie środowiska komunistycznego w największym stopniu zdradza lewicową orientację reżysera.

Nic dziwnego, że to komuniści stanowią w jego filmie nadzieję na odrodzenie dubrownickiej otwartości kulturowej. Reżyser pasuje ich pod tym względem na spadkobierców szlachty. Zwiastunem tego paradoksalnego dziedziczenia jest postawa młodego arystokraty Niko, który przystępuje do ruchu komunistycznego. Ustanawiając więź między arystokratami a robotnikami-komunistami, Zafranović stawia tezę, zgodnie z którą dubrownicka tradycja kulturowa to nie tylko tradycja szlachecka, ale tradycja wszystkich dubrowniczan - także robotników. W ujęciu reżysera komuniści przyswajają ideologicznie utopię wolności, która leży u podstaw arkadyjskiego mitu Dubrownika, dlatego nie zagrażają tradycji miasta, a chcą ją jedynie „ulepszyć” wedle mitycznego wzoru.

Idealizacja komunistów jako nowej, doskonalszej społecznie arystokracji i zdecydowane potępienie ustaszy powoduja, że film zyskuje uznanie jugosłowiańskiej władzy ${ }^{7}$. W tym kontekście za artystyczne osiagnięcie Zafranovicia należy uznać zastosowanie stylu ornamentacyjnego do popularyzacji antyfaszystowskiego i rewolucyjnego przesłania ideologicznego, które do tej pory zasadniczo wykluczało modernistyczny język filmowy z repertuaru środków służących takiej popularyzacji. Właśnie dzięki temu stylowi reżyser odświeża wypracowaną przez komunistów interpretację przemian społeczno-politycznych w okresie drugiej wojny światowej ${ }^{8}$.

${ }^{7}$ Miłośnikiem filmu Zafranovicia był także Josip Broz Tito. W wywiadzie prasowym, udzielonym w lipcu 2012 roku czarnogórskiemu dziennikowi „Pobjeda”, reżyser z dumą podaje, że Okupacja w 26 obrazach była ostatnim filmem, który Tito - leżąc w lublańskim szpitalu - obejrzał przed śmiercią w 1980 roku (i to dwukrotnie). Tę informację przekazał Zafranoviciowi doktor Zoran Hajduković, dyrektor Szpitala Wojskowego w Zagrzebiu i członek konsylium lekarskiego zajmującego się stanem zdrowia Tity (Intervju 2012).

${ }^{8} \mathrm{Z}$ tego powodu Hrvoje Turković klasyfikuje Okupacje w 26 obrazach jako przykład elitarystycznego populizmu, który polega na użyciu przez danego reżysera niekonwencjonalnego, autorskiego stylu filmowego w celu uatrakcyjnienia i uaktualnienia populistycznych treści, często występujących w szacie konwencjonalnych gatunków filmowych. W Jugosławii elitarystyczny populizm uprawiają od końca lat siedemdziesiątych do końca lat osiemdziesiątych przede wszystkim reżyserzy z kręgu szkoły praskiej (Turković 1985). 
Nie wszyscy recenzenci filmowi są w owym czasie zachwyceni tym nietradycyjnym, choć $\mathrm{w}$ sumie zgodnym $\mathrm{z}$ oficjalną ideologia, potraktowaniem tematu okupacyjnego. Niektórzy uważają Okupację w 26 obrazach za film pretensjonalny i wtórny wobec kina włoskiego 9 . Zarzut dotyczący wtórności jest poniekąd słuszny, jednak należy pamiętać, że włoskim ornamentalizmem filmowym Zafranović inspiruje się już od końca lat sześćdziesiątych. Jego filmy wyróżniają się na tle kina chorwackiego właśnie dlatego, że zdradzają powinowactwa z dziełami Włochów. Pytaniem pozostaje więc nie sama inspiracja, ale sposób jej wykorzystania. W Okupacji w 26 obrazach włoskie wzory zostają wykorzystane eklektycznie, przy czym - jak już powiedziano - najsilniejsze skojarzenia wzbudza ona ze Zmierzchem bogów Viscontiego (ze względu na temat upadku arystokracji poddanej faszystowskiemu naciskowi) oraz z twórczością Bertolucciego (w zakresie stylu narracyjno-plastycznego).

Wedle relacji Ivo Škrabalo najwięcej kontrowersji wzbudza sekwencja masakry w autobusie, która w oczach części chorwackich widzów ponad miarę eksponuje okrucieństwo ustaszy i w konsekwencji stawia w negatywnym świetle postawę wszystkich Chorwatów podczas drugiej wojny światowej (Škrabalo 1998: 380) ${ }^{10}$. Ta opinia staje się bardziej zrozumiała w politycznym kontekście tamtych czasów. Okupacja w 26 obrazach powstaje kilka lat po stłumieniu przez Josipa Broza Titę chorwackiego ruchu liberalno-narodowego, który rozwija się na przełomie lat sześćdziesiątych i siedemdziesiątych i znany jest pod nazwą chorwackiej wiosny. Škrabalo przypomina, że ten przejaw emancypacji narodowej Chorwatów konserwatywni komuniści dyskredytują, definiując go jako przedłużenie ustaszyzmu. Sposób, w jaki Zafranović przedstawia ustaszy, w odbiorze wielu Chorwatów współbrzmi z tą antychorwacką propagandą (Škrabalo 2008: 136).

\footnotetext{
${ }^{9}$ Najostrzejszą tego typu opinię o filmie Zafranovicia wyraża Nenad Polimac w artykule Pretenzije, plagijati, dosada... (Pretensje, plagiaty, nuda...), opublikowanym w tygodniku młodzieżowym „Polet” z 18 października 1978 roku. Polemikę na temat omawianego filmu, toczącą się między recenzentami w dobie jego premiery, relacjonuje Bogdan Tirnanić (Tirnanić 2008: 184-194).

${ }^{10}$ Zafranović w odpowiedzi na zarzuty, że sekwencję z autobusem-katownią wymyślił, aby przedstawić ustaszy w jak najgorszym świetle, kręci w 1979 roku (rok po Okupacji w 26 obrazach) film dokumentalny Slobodna interpretacija (Swobodna interpretacja), w którym dowodzi, że rzeczona sekwencja opiera się na faktach.
} 
Abstrahując od estetycznej i ideowej oceny sekwencji pokazującej masakrę, należy zauważyć, że polemika wokół niej świadczy o czymś więcej - o niezaspokojonej wśród Chorwatów potrzebie głębszego rozrachunku z ustaszyzmem, związanej z pragnieniem określenia i podkreślenia własnej tożsamości narodowej w obliczu murszenia jugosłowiańskiego komunizmu. Wzmiankowana potrzeba domaga się zaspokojenia także dlatego, że komuniści chętnie posługują się oskarżeniem o ustaszyzm w funkcji bicza etycznego na niepokornych politycznie chorwackich intelektualistów.

Gdyby przyjąć argumenty przeciwników filmu, można by dodać, że przedstawiona przez Zafranovicia interpretacja okresu drugiej wojny światowej trąci fałszem, tym bardziej że jej ideologiczne podłoże zostaje estetycznie uatrakcyjnione przez ornamentacyjną stylizację. Z drugiej wszakże strony właśnie owa stylizacja - prowokacyjna na tle tradycji chorwackiego (i jugosłowiańskiego) kina opowiadającego o tamtych czasach - zachęca do namysłu nie tylko nad wojenno-okupacyjną przeszłością Chorwacji, ale też nad sposobami rozliczania się z tą przeszłością.

\section{Literatura}

Gilić N., 2011, Uvod u povijest hrvatskog igranog filma, Zagreb.

Goulding D.J., 2004, Jugoslavensko filmsko iskustvo, 1945.-2001. - oslobođeni film, przeł. L. Bekavac, Zagreb.

Helman A., 1996, Palimpsesty Luchina Viscontiego, w: Mistrzowie kina europejskiego, red. K. Sobotka, Łódź.

Helman A., 2001, Urok zmierzchu. Filmy Luchina Viscontiego, Gdańsk.

Intervju - Lordan Zafranović, reditelj i scenarista: Film u službi istraživanja zla, „Рobjeda" 6.07.2012, <http://www.pobjeda.me/2012/07/06/intervju-lordan-zafrano vic-reditelj-i-scenarista-film-u-sluzbi-istrazivanja-zla/>, 15.12.2012.

Kovács A.B., 2007, Screening Modernism. European Art Cinema, 1950-1980, Chicago.

Radić D., 2000, Filmovi Lordana Zafranovića, „Hrvatski filmski ljetopis” nr 24, s. 51-75.

Rapacka J., 1984, Ztoty wiek sielanki chorwackiej. Studia z dziejów dubrownickiej literatury pastoralnej, Warszawa.

Rapacka J., 1997, Leksykon tradycji chorwackich, Warszawa.

Syska R., 2009, Filmowy modernizm, „Kwartalnik Filmowy” nr 67-68, s. 142-168. 
Škrabalo I., 1998, 101 godina filma u Hrvatskoj 1896.-1997. Pregled povijesti hrvatske kinematografije, Zagreb.

Škrabalo I., 2008, Hrvatska filmska povijest ukratko (1896-2006), Zagreb.

Tirnanić B., 2008, Crni talas, Beograd.

Turković H., 1985, Populistička i elitistička usmjerenja u razvoju jugoslavenskog igranog filma, w: H. Turković, Filmska opredjelenja, <http://www.elektronicke knj ige.com/turkovic_hrvoje/filmska_opredjeljenja/pages/004.php>, 15.12.2012.

Vojnović I., 1964, Dubrovačka trilogija, w: I. Vojnović, Pjesme. Pripovijesti. Drame, Zagreb. 
